\title{
Grody „plemienne” i „wczesnopaństwowe” na Mazowszu (IX-XI w.). Stan badań, problematyka i możliwości interpretacji
}

Słowa kluczowe: grody, Mazowsze, wczesne średniowiecze, stan badań

Keywords: strongholds, Mazovia, Early Middle Ages, state of the art

\begin{abstract}
The following text is dedicated to issues related to the chronology of early medieval strongholds built in Mazovia between the end of the $9^{\text {th }}$ and the end of the $11^{\text {th }} \mathrm{c}$. It focuses primarily on the state of archeological research.
\end{abstract}

Zagadnienie budownictwa grodowego na Mazowszu w okresie formowania się państwa polskiego z pozoru wydaje się stosunkowo dobrze rozpoznane. Można tu przywołać wydany jeszcze w latach siedemdziesiątych ubiegłego wieku obszerny katalog grodzisk, studia osadnicze Marii Miśkiewicz, syntetyczne ujęcia Marka Dulinicza, czy monografie poszczególnych stanowisk, z niedawnymi opracowaniami dwóch głównych grodów dzielnicy - Płocka i Czerska. Niestety, w rzeczywistości większość syntez bazuje - z konieczności - na stanie wiedzy z końca lat siedemdziesiątych XX w., wyniki badań wielu stanowisk, w tym kluczowych, pozostają nieopracowane pomimo kilkudziesięciu niekiedy lat od zakończenia wykopalisk, a wiele z nich jest przebadanych w nikłym stopniu. Niemniej jednak warto przyjrzeć się ponownie mazowieckim grodziskom, choćby po to, aby ocenić zawarty w tych obiektach niewykorzystany potencjał informacyjny. 
Już na początku trzeba jednak zaznaczyć, że określenie terytorialnego zakresu pojęcia „Mazowsze” w wiekach średnich jest zadaniem wyjątkowo skomplikowanym ${ }^{1}$. Nie można tu wykorzystać kryteriów geograficznych. Obszar dorzecza środkowej Wisły pozbawiony jest naturalnych barier wyodrębniających ziemie wchodzące w skład historycznego Mazowsza, nawet w jego ustabilizowanych szesnastowiecznych granicach ${ }^{2}$. W tej sytuacji analizę ograniczono do terytorium pozostającego w XIV w. domeną książąt mazowieckich, choć z oczywistych powodów dla okresu nas tu interesującego jest on anachronizmem. Warto jednak podkreślić, że te właśnie granice przyjmowane są - świadomie lub nie - przez większość archeologów zajmujących się studiami nad mazowieckim wczesnym średniowieczem ${ }^{3}$.

Bardzo ograniczony jest zasób źródeł pisanych wspominających bezpośrednio poszczególne obiekty. Należy tu wymienić przede wszystkim słynną listę grodów z falsyfikatu mogileńskiego ${ }^{4}$. Nie miejsce tu, aby szczegółowo omawiać wyjątkowo złożoną problematykę interpretacji tego dokumentu ${ }^{5}$. Warto jednak pamiętać, że do niedawna było to jedno z podstawowych „narzędzi datujących” stosowanych przez

1 E. Kowalczyk, Granice Mazowsza we wczesnym średniowieczu. Ocena stanu badań, [w:] Problemy przeszłości Mazowsza i Podlasia, red. M. Dulinicz, Warszawa 2004, s 167-172; tam też dalsza literatura.

2 J. Tyszkiewicz, Środowisko geograficzne w pradziejach i średniowieczu, [w:] Dzieje Mazowsza. Tom 1, red. H. Samsonowicz, Pułtusk 2006, s. 43-67.

3 Zob. m.in.: M. Dulinicz, Mazowsze w X wieku, [w: ] Ziemie polskie w X wieku i ich znaczenie w ksztattowaniu się nowej mapy Europy, red. H. Samsonowicz, Kraków 2000, s. 200-213; tenże, Mazowsze we wczesnym średniowieczu: jego związki z „państwem gnieźnieńskim”, [w:] Civitas Schinesghe cum pertinentiis , red. W. Chudziak, Toruń 2003, s. 89-119; tenże Stan i potrzeby badań nad wczesnym średniowieczem Mazowsza, [w:] Stan i potrzeby badań nad wczesnym średniowieczem w Polsce - 15 lat później, red. W. Chudziak, S. Moździoch, Toruń 2006, s. 345-271; E. Kowalczyk, Granice Mazowsza, s. 164; J. Ościłowski, Uwarunkowania geograficzne lokalizacji grodów na pótnocnym Mazowszu (X- pocz. XIII w.): problematyka badań interdyscyplinarnych, Rocznik Muzeum Mazowieckiego w Płocku 19 (2011), s. 7-40 (dalej Uwarunkowania I).

4 Codex diplomaticus et commemorationum Masoviae generalis, wyd. J. K. Kochanowski, Warszawa $1919, \mathrm{nr} 22$.

5 Zob. m.in.: S. Arnold, Początki biskupstwa ptockiego w świetle falsyfikatów mogileńskich, Rocznik Towarzystwa Naukowego w Płocku 1 (1929), s. 3-24; J. Płocha, Najdawniejsze dzieje opactwa benedyktynów w Mogilnie, Wrocław 1969, zwłaszcza s. 160-168; G. Labuda, Początki klasztoru w świetle źródet pisanych, [w: ] Materialy sprawozdawcze z badań zespołu pobenedyktyńskiego w Mogilnie 1, Warszawa 1978, s. 32-35; H. Łowmiański, Początki Polski. Polityczne i spoteczne procesy ksztattowania się narodu do początku wieku XIV, t. 6, cz. 1, Warszawa 1985, s. 306-320. 
archeologów badających mazowieckie grodziska ${ }^{6}$. Można tu jeszcze przywołać informacje o Płocku zawarte w kronice Galla, pojawiające się w kontekście wydarzeń z dzieciństwa i młodości Bolesława Krzywoustego ${ }^{7}$. Już do lat czterdziestych XII w. odnoszą się wzmianki o grodach w Wiźnie i Czersku w Latopisie Ipatijewskim ${ }^{8}$. Nie może być zatem zaskoczeniem stwierdzenie, że to właśnie od archeologii oczekuje się wzbogacenia stanu naszej wiedzy o wczesnych dziejach regionu, jego strukturze administracyjnej, ośrodkach centralnych, ich kształcie przestrzennym i funkcjach.

Już na wstępie należy jednak zaznaczyć, że badania nad grodziskami mazowieckimi maja stosunkowo późną metrykę̣. Obiekty te, choć wyróżniające się formą terenową, pozostawały poza zainteresowaniem pierwszych archeologów-amatorów działających tu od połowy XIX w. Ich uwagę przyciągały przede wszystkim dostarczające atrakcyjnych znalezisk cmentarzyska z grobami w obudowach kamiennych. Wyjątkiem są inwentaryzacje i opisy grodzisk nadnarwiańskich sporządzane pod koniec XIX stulecia przez Ludwika de Fleury i Zygmunta Glogera. W okresie międzywojennym aktywność archeologów ograniczała się do inwentaryzacji grodzisk, prowadzonej przez Romana Jakimowicza.

Pierwsze planowe badania miały miejsce dopiero w latach pięćdziesiątych XX w., a zapoczątkowały je wykopaliska w Starym Bródnie. Pod koniec tej dekady rozpoczęto też wieloletnie badania nad wczesnośredniowiecznym Płockiem ${ }^{10}$. Lata sześćdziesiąte XX w. przyniosły kompleksowy program badawczy Zakładu Polskiego Atlasu Archeologicznego Instytutu Historii Kultury Materialnej PAN, podsumowany wy-

6 „Na szczęście dokument mogileński jest bezcennym uzupełnieniem naszych informacji o grodach z XI stulecia” (M. Dulinicz, Stan i potrzeby, s. 255).

7 Monumenta Poloniae Historica, Ser. 2, t. 2, wyd. K. Maleczyński, Kraków 1952, s. 16-18.

8 Polnoe sobrane russkich letopisej II: Ipat'evskaja letopis, Moskva 1962, szp. 318.

9 Szczegółowe omówienie historii badań - zob. m.in: M. Miśkiewiczowa, Mazowsze płockie we wczesnym średniowieczu, Warszawa 1982, s. 18-22; J. Ościłowski, Sieć grodowa na Wysoczyźnie Kolneńskiej we wczesnym średniowieczu. Ze studiów nad pograniczem mazowiecko-prusko-jaćwieskim, Światowit 67 (2006), s. 81-107, tu s. 86-87; tenże, Uwarunkowania I, s. 19-27; tenże, Uwarunkowania geograficzne lokalizacji grodów na południowym Mazowszu (X-połowa XIII w.). Problematyka badań interdyscyplinarnych, Rocznik Muzeum Mazowieckiego w Płocku 20 (2016), s. 71-118, tu s. 79-82 (dalej Uwarunkowania II). W cytowanych pracach dalsza literatura.

10 A. Gołembnik, M. Trzeciecki, Stan badań nad aglomeracja płocka w okresie od XI w. do czasu powstania miasta samorządowego, [w:] Płock Wczesnośredniowieczny, red. A. Gołembnik, Warszawa 2011, s. 27-38; tam też starsza literatura. 
daniem katalogu grodzisk ${ }^{11}$. Przeprowadzono wówczas szeroko zakrojone poszukiwania, w wyniku których określono lokalizację wielu nieznanych dotąd obiektów, sporządzono szczegółową inwentaryzację wszystkich grodzisk. Podjęte na większości obiektów badania sondażowe dostarczyć miały danych dotyczących stanu zachowania nawarstwień i materiałów pozwalających na określenie chronologii obiektów. Równolegle z tymi pracami rozpoczęto też planowe wykopaliska na wybranych grodziskach, między innymi w Sypniewie, Święcku-Strumianach, Czersku, czy Szeli$\operatorname{gach}^{12}$. Na ten okres datować też można pierwsze prace na grodziskach Mazowsza północno-wschodniego, pozostającego poza zasięgiem wspomnianego katalogu, przede wszystkim badania sondażowe w Starej Łomży i Wiźnie ${ }^{13}$.

Publikacja katalogu grodzisk Mazowsza i Podlasia w 1976 r. przyniosła - paradoksalnie - osłabienie zainteresowania problematyką wczesnośredniowiecznych obiektów obronnych. W latach osiemdziesiątych XX w. na Mazowszu płockim prowadzono wykopaliska w Wyszogrodzie, a w ograniczonym zakresie także w Proboszczewicach, Szreńsku i Płońsku. W tym czasie rozpoczęły się natomiast wieloletnie badania Instytutu Archeologii Uniwersytetu Warszawskiego na ziemi łomżyńskiej. W ich trakcie przeprowadzono prace wykopaliskowe na kilkunastu obiektach, w tym tak istotnych dla poruszanej tu problematyki, jak zespół osadniczy w Starej Łomży, czy grodziska w Wiźnie i Truszkach-Zalesiu ${ }^{14}$. Na Mazowszu południowym kontynuowano badania w Czersku, rozpoczęto też wykopaliska w Grodzisku nad Liwcem ${ }^{15}$. Z tym okresem wiążą się też dwie archeologiczne monografie wczesnośredniowiecznego Mazowsza i syntetyczne podsumowanie stanu badań ${ }^{16}$.

$\mathrm{Z}$ prac prowadzonych $\mathrm{w}$ ciągu ostatniego ćwierćwiecza wymienić należy przede wszystkim program badań weryfikacyjnych „plemiennych” grodzisk Mazowsza.

11 I. Górska i in., Grodziska Mazowsza i Podlasia (w granicach dawnego województwa warszawskiego), Wrocław 1976.

12 M. Miśkiewiczowa Mazowsze płockie, s. 21; J. Ościłowski Uwarunkowania I, s. 21-22; S. Suchodolski, Historia badań archeologicznych w Czersku, [w: Czersk, Wzgórze Zamkowe. Badania 1974-1983, red. P. Urbańczyk, M. Trzeciecki, Warszawa 2016, s. 17-28.

13 J. Ościłowski, Sieć grodowa, s. 86.

14 Tamże, s. 86-87.

15 S. Suchodolski, Historia badań, s. 24-26; J. Ościłowski, Uwarunkowania II, s. 81-82.

16 M. Miśkiewiczowa, Mazowsze wschodnie we wczesnym średniowieczu, Warszawa 1981; taż, Mazowsze płockie; M. Dulinicz, Stan i potrzeby badań nad osadnictwem wczesnośredniowiecznym na Mazowszu (VI-XI w.), [w:] Stan i potrzeby badań nad wczesnym średniowieczem w Polsce. Materialy z konferencji Poznań 14-16 grudnia 1987 roku, red. Z. Kurnatowska, Wrocław 1992, s. 243-261. 
W jego wyniku uzyskano serię dat dendrochronologicznych i radiowęglowych dla kilkunastu obiektów, przede wszystkim z interesującego nas tu okresu IX-XI w. ${ }^{17}$ Konsekwencją omawianych badań było podjęcie na nowo wykopalisk na grodzisku w Nasielsku. Na uwagę zasługują także badania ratownicze, prowadzone przede wszystkim w związku z programami rewitalizacji ośrodków miejskich. Wymienić tu należy wieloletnie prace na Wzgórzu Tumskim w Płocku, wznowione w latach dziewięćdziesiątych XX w. wykopaliska w Starym Bródnie, czy niedawno prowadzone badania w Płońsku i w Grudusku ${ }^{18}$. W ostatnich latach Narodowy Instytut Dziedzictwa realizuje także program inwentaryzacji wybranych obiektów, obejmujący sporządzanie numerycznych modeli terenu, prospekcje powierzchniowe i badania geofizyczne $^{19}$.

O wiele gorzej przedstawia się stan opracowania wyników omawianych tu wykopalisk. O ile materiały z kolejnych sezonów badań prowadzonych latach pięćdziesiątych i sześćdziesiątych XX w. były udostępniane w formie co najmniej komunikatów i zostały podsumowane w przywoływanym tu wielokrotnie katalogu grodzisk, to wyniki badań prowadzonych w latach osiemdziesiątych i dziewięćdziesiątych często oczekują dopiero na pełne opracowanie ${ }^{20}$. Dotyczy to szczególnie stanowisk badanych na ziemi łomżyńskiej, w przypadku których nie powstały nawet wstępne sprawozdania składane w archiwach urzędów konserwatorskich, a większość materiałów zaginęła bądź uległa rozproszeniu. Prac o charakterze monograficznym doczekały się wczesnośredniowieczny Płock i Czersk, bardzo istotne znaczenie dla omawianej tu problematyki mają pełne publikacje wyników wykopalisk w Sypniewie i Święcku-Strumianach ${ }^{21}$.

17 M. Dulinicz, Frühmittelalterliche Burgen in Mazowien: die ersten Ergebnisse der deutsch-polnischen Untersuchungen, [w:] Frühmittelalterlicher Burgenbau im Mittel - und Osteuropa, red. J. Henning, A. Ruttkay, Bonn 1998, s. 267-274; tenże, Badania grodzisk mazowieckich, [w: ] Osadnictwo i architektura ziem polskich $w$ dobie zjazdu gnieźnieńskiego, red. A. Buko, Z. Świechowski, Warszawa 2000, s. 145-158; tenże, Stan i potrzeby, s. 254-256; M. Dulinicz, T. Ważny, Dendrochronologia o datowaniu mazowieckich grodzisk, Rocznik Mazowiecki 16 (2004), s. 9-27.

18 J. Ościłowski, Uwarunkowania I, s. 26; tenże, Uwarunkowania II, s. 86; W. Pastuszka, Grudusk - niezwykła podróż do średniowiecznego grodu, https://archeowiesci.pl/2011/03/27/grudusk-niezwykla-podroz-do-sredniowiecznego-grodu/ [dostęp z dnia 29.XI.2017].

19 https://mapy.zabytek.gov.pl/nid/ [dostęp z dnia 29.XI.2017].

20 Pełne zestawienia publikowanych sprawozdań z badań: M. Miśkiewiczowa, Mazowsze płockie, s. 130-199; J. Ościłowski, Sieć grodowa; tenże Uwarunkowania I; tenże, Uwarunkowania II.

21 W. Szafrański, Płock we wczesnym średniowieczu, Wrocław 1983; F. Biermann, Sypniewo: ein frühmittelalterlicher Burg-siedlungkomplex in Nordmasowien, Warszawa 2006; D. Jaskanis, Święck: wczesnośredniowieczny zespót osadniczy na pótnocno-wschodnim Mazowszu, Warszawa 2008; Płock 
Należy mieć nadzieję, że podobne monografie podsumują wieloletnie badania w Bródnie Starym i Truszkach-Zalesiu.

Dzięki omówionym wyżej badaniom możemy dziś stwierdzić, że na interesującym nas obszarze zarejestrowano 73 grodziska datowane na okres między VII a XIV w. W przypadku 39 spośród nich możemy w mniejszym lub większym przybliżeniu określić datę ich powstania na X-XI w. Bardzo zróżnicowany jest stopień rozpoznania poszczególnych obiektów - tylko nieliczne były przedmiotem badań szerszych niż sondażowe - można tu wymienić Płock, Czersk, Sypniewo, Święck-Strumiany, Stare Bródno, Wyszogród, Truszki-Zalesie, Starą Łomżę, Szreńsk, czy Grudusk. Dla 13 grodzisk udało się uzyskać daty dendrochronologicznie lub radiowęglowe odnoszące się do czasu budowy założeń. Zakres badań sprawia, że niewielka jest liczba wiarygodnych danych dotyczących rozplanowania, fortyfikacji i zabudowy grodów. W większości przypadków brak jest też kompleksowego rozpoznania zaplecza osadniczego. Dlatego prezentowana tu próba rekonstrukcji zmian „grodowego krajobrazu” Mazowsza w X i XI w. to jedynie propozycja, którą winny zweryfikować szczegółowe opracowania źródeł archeologicznych.

Trudno tu wszechstronnie omawiać geografię osadniczą ziem środkowego dorzecza Wisły w starszych fazach wczesnego średniowiecza. Zgodnie z propozycją M. Dulinicza można ten obszar traktować jako strefę przenikania się wpływów północno-zachodnich, silnych zwłaszcza na Mazowszu płockim, powiązanym z ziemią chełmińską, Kujawami i północną Wielkopolską oraz południowo-wschodnich, czytelnych w dorzeczu środkowego Bugu i Narwi, o wyraźnych nawiązaniach do wschodniosłowiańskich zespołów typu Łuka Rajkowiecka ${ }^{22}$. Bardzo istotne, a nie do końca rozpoznane znaczenie, miało też sąsiedztwo ludów bałtyjskich ${ }^{23}$. W źródłach archeologicznych dobrze rysuje się obraz niewielkich grup ludzkich o autarkicznej

Wczesnośredniowieczny, red. A. Gołembnik, Warszawa 2011; Czersk, Wzgórze Zamkowe. Badania 1974-1983, red. P. Urbańczyk, M. Trzeciecki, Warszawa 2016.

22 M. Dulinicz Mazowsze we wczesnym, s. 92 n; tenże, Mazowsze w IX-XIII w., [w:] Problemy przeszłości Mazowsza i Podlasia, red. M. Dulinicz, Warszawa 2004, s. 187-206; tenże, Mazowsze we wcześniejszym średniowieczu (do końca X w.): szkic archeologiczny, [w:] Dzieje Mazowsza. Tom 1, red. H. Samsonowicz, Pułtusk 2006, s. 67-107, tu s. 69 n; zob. też. K. Skrzyńska, Wczesnośredniowieczne pogranicze polsko-ruskie w dorzeczu środkowego Bugu - główne problemy badawcze, [w:] Stan badań archeologicznych na pograniczu polsko-białoruskim od wczesnego średniowiecza po czasy nowożytne, red. H. Karwowska, A. Andrzejowski, Białystok 2006, s. 51-62.

23 W. Wróblewski, Ziemie pruskie i jaćwieskie w okresie plemiennym (VII/VIII-XII/XIII wiek), [w:] Stan i potrzeby badań nad wczesnym średniowieczem w Polsce - 15 lat później, red. W. Chudziak, S. Moździoch, Toruń 2006, s. 285-310; tam też dalsza literatura. 
gospodarce i egalitarnej kulturze materialnej, zasiedlających w VII-IX w. strefę dorzeczy Wisły, Bugu i Narwi. Cechą charakterystyczną tego okresu jest także brak założeń obronnych. Datowane na VII-VIII w. grodzisko w Szeligach stanowi raczej wyjątek i trudno je traktować jako pierwsze ogniwo w łańcuchu rozwoju budownictwa grodowego w tym regionie ${ }^{24}$.

Pierwsze grody pojawiły się tu między schyłkiem IX a połową X w. Na ten okres możemy datować funkcjonowanie co najmniej 14 obiektów (ryc. 1). W przypadku 8 $\mathrm{z}$ nich chronologię ustalono na podstawie analiz dendrochronologicznych lub datowań C14 (Mokrzk, Nasielsk, Raciąż, Słupno, Sypniewo, Święck-Strumiany, Truszki-Zalesie, Wola Szydłowska). Dla określenia czasu powstania 2 grodów podstawą była analiza zespołów znalezisk (Bogurzyn, Bródno Stare). Datowanie 4 obiektów na okres przed połową $\mathrm{X}$ w. ma charakter przede wszystkim intuicyjny (Bocheń, Brudzeń Duży, Świerże-Chmielewo, Zwola Poduchowna ${ }^{25}$. Warto zwrócić uwagę na nierównomierność ich rozmieszczenia. Aż 7 założeń znajduje się na terenie Mazowsza płockiego (Bogurzyn, Brudzeń Duży, Mokrzk, Nasielsk, Raciąż, Słupno, Wola Szydłowska). Ze strefą północno-wschodnią wiązać można grodziska w Sypniewie, Święcku-Strumianach, Świerżach-Chmielewie i Truszkach-Zalesiu ${ }^{26}$. Na Mazowszu południowym i południowo-wschodnim z omawianym okresem możemy w sposób pewny wiązać powstanie grodu w Starym Bródnie, a prawdopodobnie także w Bocheniu i Zwoli Poduchownej.

Najstarszym z omawianych obiektów jest gród w Nasielsku, datowany na lata sześćdziesiąte IX w. U schyłku tego stulecia zbudowano gród w Woli Szydłowskiej, funkcjonujący prawdopodobnie stosunkowo krótko. Na sam początek X w. datować można budowę grodów w Mokrzku, Raciążu i Sypniewie. Nieco później - u schył-

24 M. Dulinicz, Miejsca, które rodza wtadzę (najstarsze grody stowiańskie na wschód od Wisty), [w: ] Człowiek, sacrum, środowisko. Miejsca kultu we wczesnym średniowieczu, red. S. Moździoch, Wrocław 2000, s. 85-98; tenże, Mazowsze we wcześniejszym, s. 70-72.

25 J. Ościłowski, Uwarunkowania I; tenże, Uwarunkowania II. W cytowanych pracach dalsza literatura.

26 Zdaniem W. Wróblewskiego fazę „plemienną” posiada też założenie obronne w Grodzisku nad Liwcem - zob.: W. Wróblewski, U źródet kasztelanii liwskiej. Wczesnośredniowieczne struktury osadnicze w dorzeczu Liwca, [w: ] Najstarsze dzieje Podlasia w świetle źródet archeologicznych, red. B. Bryńczak, P. Urbańczyk, Siedlce 2001, s. 205-228, tu s. 209-211. Do czasu wstępnego choćby opublikowania materiałów z badań trudno jednak odnieść się do tej hipotezy. Z podobnych powodów niemożliwa jest weryfikacja postulowanego swego czasu przez M. Dulinicza (przede wszystkim na podstawie przesłanek intuicyjnych) datowania na okres przed połową X w. początków grodów w Ciechanowie, Szreńsku i Wyszogrodzie - zob. M. Dulinicz, Mazowsze we wcześniejszym, s. 91-93. 
ku pierwszej ćwierci X w. - powstały założenia w Słupnie, Święcku-Strumianach i Truszkach-Zalesiu. Bródno Stare i Bogurzyn możemy datować na okres przed połową $\mathrm{X}$ w. na podstawie chronologii znalezisk ${ }^{27}$.

Grody lokowano przede wszystkim na obszarach pogranicznych stref wcześniej zasiedlonych. Taką sytuację obserwujemy w przypadku Słupna, Mokrzka, Nasielska i Raciąża, założonych na słabo zasiedlonych peryferiach skupisk osadniczych w dorzeczach Słupianki, Skrwy i Wkry ${ }^{28}$. Niejasna jest struktura osadnictwa w rejonie wzniesionego przed połową X w. grodu w Bródnie Starym. W jego bezpośrednim otoczeniu brak jest stanowisk, które można datować na IX-początek X w. Może to być jednak efekt ograniczonej dostępności do badań terenu, położonego w granicach aglomeracji warszawskiej.

Najbardziej interesująca jest jednak grupa grodów zakładana „na surowym korzeniu” wraz z całym towarzyszącym im zapleczem osadniczym. Występują one wyłącznie w północnej części analizowanego tu terytorium, nadto pięć spośród nich - Bogurzyn, Wola Szydłowska, Sypniewo, Świerże-Chmielewo i Święck-Strumiany - układa się w wyraźny równoleżnikowy pas. Ostatni gród zaliczony do tej grupy to założenie w Truszkach-Zalesiu, położone na północno-wschodnim skraju Mazowsza, w strefie szeroko pojętego pogranicza bałtyjsko-słowiańskiego ${ }^{29}$. Wymienione

27 K. Musianowicz, Gród i osada podgrodowa w Bródnie Starym koło Warszawy, Materiały Wczesnośredniowieczne 4 (1956), s. 7-34; T. Górska i in., Grodziska, s. 25; M. Dulinicz, The first dendrochronological datings of the strongholds in northern Mazovia, [w:] Origins of Central Europe, red. P. Urbańczyk, Warszawa 1997, s. 137-141; tenże, Badania grodzisk mazowieckich, s. 153-156; 2006: 92, przyp. 39; K. Matusiak, Wczesnośredniowieczne osadnictwo w rejonie Mokrzka i Bielska, Warszawa 2000 (maszynopis pracy magisterskiej w archiwum Instytutu Archeologii Uniwersytetu Warszawskiego); E. Marczak, „Nikienki” czyli Prusowie na Mazowszu? Wstępne wyniki badań archeologicznych w Truszkach-Zalesiu, woj. podlaskie, [w:] Przez granice czasu. Księga jubileuszowa poświęcona Profesorowi Jerzemu Gąssowskiemu, red. A. Buko, W. Duczko, Pułtusk 2008, s. 119-128, tu s. 122-123; F. Biermann, The small Early Medieval lowland ringforts in Northern Mazovia and their counterparts in the northern West-Slavic territory, [w:] Grody średniowiecznego Mazowsza. Księga poświęcona pamięci Marka Dulinicza, red. M. Żurek, M. Krasna-Korycińska, Warszawa 2015, s. 39-49, tu s. 44.

28 T. Górska i in., Grodziska, s. 81-86, 108-111; M. Dulinicz, Rozwój osadnictwa w dolinie Stupianki w pradziejach i średniowieczu, [w:] Osadnictwo pradziejowe i wczesnośredniowieczne w dorzeczu Stupianki, pod Ptockiem, red. M. Dulinicz, Warszawa 1998, s. 209-215, tu. s. 199-216; tenże, Mazowsze we wczesnym, s. 98-102; tenże, Mazowsze we wcześniejszym, s. 91n; Matusiak 2000.

29 Zdaniem Ewy Marczak gród w Truszkach-Zalesiu wiązać należy już ze strefą bałtyjską (E. Marczak, „Nikienki”, s. 126n; odmiennie M. Dulinicz, Mazowsze we wcześniejszym, s. 89). Zarówno jednak forma grodu, technika budowy fortyfikacji, jak i przede wszystkim technologiczne i stylistyczne cechy ceramiki nie znajdują analogii na ziemiach pruskich, nie odbiegają natomiast od wyżej wymienionych obiektów. 
tu grody stanowily centra mikroregionów osadniczych złożonych z kilku, maksymalnie kilkunastu stanowisk i śladów osadniczych, odizolowanych od siebie nawzajem, a także od stref dawniej zasiedlonych ${ }^{30}$.

Wszystkie omówione wyżej obiekty tworzą grupę bardzo jednorodną pod względem formy, techniki budowy i organizacji przestrzeni (ryc. 2). Budowano je w dolinach małych cieków, na kępach położonych w strefie zalewowej lub nadzalewowej. Same grodziska są niewielkie, o powierzchni obejmującej od 50 do 70 arów. Mają plan zbliżony do regularnego okręgu i wały o szerokości niewspółmiernie dużej do rozmiarów całego założenia, wznoszone w różnych wariantach konstrukcji przekładkowej. W najlepiej rozpoznanych obiektach (Sypniewo, Święck-Strumiany) ślady zabudowy wnętrza były bardzo nikłe i koncentrowały się wzdłuż wewnętrznego lica wału, a pośrodku pustego dziedzińca znajdowała się drewniana studnia. Dla omawianych grodów charakterystyczne są znaleziska militariów, przedmiotów importowanych i monet, głównie arabskich dirhemów, nieobecne właściwie na osadach otwartych z tego okresu. Wśród znalezisk masowych zwraca uwagę bardzo wysoki, sięgający niekiedy $100 \%$, udział naczyń silnie obtaczanych zdobionych żłobkami dookolnymi, na osadach otwartych Mazowsza masowo pojawiających się dopiero po połowie XI stulecia. W zestawie form dominują garnki baniaste i dwustożkowate oraz formy z wyodrębnioną szyjką nawiązujące do młodszych o prawie 100 lat tzw. naczyń drohiczyńskich ${ }^{31}$.

Jako najbliższe analogie do omawianych obiektów przywołuje się niewielkie grody typu Tornow, charakterystyczne dla obszarów północno-zachodniej Słowiańszczyzny w okresie między połową IX a połową X w. Kwestia genezy tych obiektów jest nadal dyskutowana, warto zwrócić uwagę, że jedne z najwcześniejszych takich założeń znamy z terenu Wielkopolski. Najbliżej interesujących nas terenów występują one na ziemi chełmińskiej i w Polsce środkowej, nie spotykamy ich z kolei w północnej Małopolsce, czy w strefie środkowego dorzecza Bugu, dla których typowe

30 M. Miśkiewiczowa, Mazowsze płockie, s. 94 n; F. Biermann, Das 10. Jahrhundert in Mazovien umd Podlasien (Nordostpolen). Eine wirtschaftgeschichtliche Betrachtung, [w: ] Europa in 10. Jahrhundert. Archäologie eine Aufbruchszeit, red. J. Henning, Mainz 2002, s. 249-265, tu s. 261-262; tenże, Sypniewo, s. 12 n; D. Jaskanis, Święck, s. 16-18.

31 F. Biermann, Sypniewo, s. 82-86; 154-157; tenże, Das 10. Jahrhundert... 254-261; tenże, The small Early Medieval, s. 43-45; M. Dulinicz, Mazowsze we wcześniejszym, s. 82n; M. Trzeciecki, Początki Płocka, [w:] Ptock Wczesnośredniowieczny, red. A. Gołembnik, Warszawa 2011, s. 55-100, tu s. 79-81; tenże, Ceramika płocka między XI a XIX wiekiem. Studium archeologiczne, Warszawa 2016, s. 134-135. W cytowanych pracach dalsza literatura 
są raczej duże założenia otoczone nierzadko kilkoma pierścieniami wałów, których głównym elementem konstrukcyjnym jest piaszczysty szaniec ${ }^{32}$.

Dyskutowana jest funkcja omawianej grupy grodów. Przyjmuje się różne hipotezy, podkreślające ich znaczenie militarne (systemy obronne, kontrola terytoriów i szlaków handlowych) lub wskazuje się na ich związek z procesami centralizacji władzy, dokonującymi się w okresie kształtowania się struktur państwowych w tej części Słowiańszczyzny. Większość badaczy wiąże powstanie grodów typu Tornow z okresem emancypacji „plemiennych” elit rywalizujących w walce o władzę i podkreślających swój prestiż kreowaniem ośrodków centralnych, stających się miejscami nie tyle sprawowania, co manifestowania władzy i redystrybucji dóbr, która w społeczeństwach „wodzowskich” była jedynym sposobem na zapewnienie względnej stabilności władzy politycznej, a także ochrony przed agresją ze strony konkurentów ${ }^{33}$. W świetle tego, co wiemy o mazowieckich grodach „plemiennych” ta właśnie teoria wydaje się najbardziej prawdopodobna. Wybór miejsc wcześniej niezasiedlonych lub położonych na peryferiach starszych skupisk osadniczych dobrze wpisywałby się w strategię kreowania nowego porządku wprowadzaną przez elity wyłaniające się z egalitarnej społeczności „plemiennej”. Na ich „wodzowski” charakter wskazywałyby stosunkowo liczne znaleziska militariów i przedmiotów importowanych, pochodzące z lepiej przebadanych grodów, między innymi z Sypniewa.

Rozważając geograficzne i kulturowe uwarunkowania powstania mazowieckich grodów okresu „plemiennego” należy także przypomnieć hipotezę o istnieniu szlaku łączącego środkowe Podnieprze via północne Mazowsze i ziemie pruskie z nadbał-

32 Zob. m.in.: J. Henning, Archäologische Forschungen an Ringwällen in Niederungslage: Der Niederlausitz als Burgenlandschaft des östlichen Mitteleuropa im frühen Mittelalter, [w:] Frühmittelalterlicher Burgenbau in Mittel - und Osteuropa, red. J. Henning, A. Ruttkay, Bonn 1998, s. 8-21; M. Dulinicz, Mazowsze we wczesnym, s. 102-105; tenże, Mazowsze we wcześniejszym, s. 91-95; F. Biermann, Sypniewo, s. 154 n; tenże, The small Early Medieval, s. 39-49; M. Kara, Najstarsze państwo Piastów - rezultat przetomu czy kontynuacji? Studium archeologiczne, Poznań 2009, s. 208 n. W cytowanych pracach dalsza literatura.

33 P. Urbańczyk, The origins of towns on the outskirts of medieval Europe - Poland, Norway and Ireland, Archaeologia Polona 32 (1994), s. 109-127; tenże, Wczesna urbanizacja ziem polskich, [w:] Civitas \& villa. Miasto i wieś w średniowiecznej Europie Środkowej, red. C. Buśko, Wrocław 2002, s. 37-47; tenże, Trudne początki Polski, Wrocław 2008, s. 84 n; F. Biermann, K. Frey, Burgwall und Macht. Über die Burgen des 9-10 Jh. am Teltow und in Berliner Raum, Przegląd Archeologiczny 49 (2001), s. 59-83; F. Biermann, Sypniewo, s. 164-168, tenże, The small Early Medieval, s. 45-46; M. Dulinicz Mazowsze we wcześniejszym, s. 94-95; M. Kara, Najstarsze państwo, s. 221 n. W cytowanych pracach dalsza literatura. 
tyckim emporium Truso ${ }^{34}$. Nie można wykluczyć, że kształtowanie się na pograniczu słowiańsko - pruskim strefy transferu rozmaitych dóbr mogło być czynnikiem wpływającym na wybór takiej a nie innej lokalizacji dla części z omawianych tu grodów. Może to wskazywać na dążenie „plemiennych” wodzów do aktywnego udziału w wymianie, będącej drugim obok wojny sposobem pozyskiwania dóbr niezbędnych dla utrzymania prestiżu, a co za tym idzie - władzy. W tym kontekście warto też zwrócić uwagę na sąsiadujące bezpośrednio z Mazowszem ziemie pruskie, gdzie od IX w. masowo pojawiają się niewielkie założenia obronne, także wiązane z dokonującymi się procesami emancypacji elit. Zagadnienie możliwości wzajemnego oddziaływania obu kręgów kulturowych pozostaje jednak jak dotąd poza zainteresowaniem badaczy, koncentrujących się - z nielicznymi wyjątkami - bądź wyłącznie na problematyce „słowiańskiej”, bądź „pruskiej”35.

Należy w tym miejscu wspomnieć o dwóch obiektach, których datowanie także można odnosić do okresu przed połową X w., a które odróżniają się od wyżej omówionych (ryc. 3). Pierwszym z nich jest grodzisko w Brudzeniu Dużym, położone na wyniosłym cyplu górującym nad doliną Skrwy, odciętym od wysoczyzny co najmniej dwiema liniami wałów ${ }^{36}$. Drugi to rozległe grodzisko w Zwoli Poduchownej, $\mathrm{z}$ dwoma pierścieniami silnie zniszczonych dziś fortyfikacji, zamykających obszar o powierzchni blisko 300 arów $^{37}$. Stan badań obu obiektów pozwala jedynie na hipotetyczne wiązanie ich z okresem „plemiennym”, pozostaje więc zasygnalizować ich obecność i zwrócić uwagę na podobieństwo założenia w Zwoli do nieodległych terytorialnie, datowanych na $\mathrm{X}$ w. grodzisk, przez $\mathrm{M}$. Dulinicza określonych swego czasu jako „typ Chodlik-Huszlew”38.

Zarówno stan badań, jak i trudności z precyzyjnym datowaniem czasu funkcjonowania poszczególnych obiektów sprawiają, że bardzo trudno odtworzyć przebieg

34 W. Wróblewski, T. Nowakiewicz, M. Bogucki, Terra desolata. Wczesnośredniowieczna Galindia wświetle badań mikroregionu jeziora Salęt, [w:] Studia Galindzkie. Tom 1, red. W. Wróblewski, Warszawa 2003, s. 157-180, tu s. 167-168; M. Bogucki, The Viking Age ports of trade in Poland, Eesti Arheoloogia Ajakiri 8 (2004), s. 100-127.

35 Zob. m.in. W. Wróblewski, Ziemie pruskie; T. Nowakiewicz, Baltic communities present in today's Polish territory between 700 and 1000 AD, [w: ] The Past Societies. Polish lands from the first evidence of human presence to the early Middle Ages, Volume 5: 500 AD - 1000 AD, red. P. Urbańczyk, M. Trzeciecki, Warszawa 2016, s. 172-221. W cytowanych pracach dalsza literatura.

36 I. Górska i in., Grodziska, s. 27.

37 Tamże, s. 171-173; B. Bryńczak, A. Martyniuk, Zwola, st. 1, gm. Miastków Kościelny, woj. siedleckie, AZP 64-74/1, Informator Archeologiczny. Badania 1997 (2006), s. 230-231.

M. Dulinicz, Mazowsze w IX-XIII w., s. 191-192. 
procesu zastępowania centrów „plemiennych” przez sieć grodów związanych już $\mathrm{z}$ administracją państwową. Dane archeologiczne dotyczące okresu, w którym Mazowsze zostało podporządkowane państwu pierwszych Piastów są nieliczne. Większość domniemanych inwestycji piastowskich rozpoznana jest w nikłym stopniu a ich jedenastowieczna chronologia budowana jest przede wszystkim na podstawie wzmianek w falsyfikacie mogileńskim ${ }^{39}$. Można jednak dostrzec pewne prawidłowości, które wskazują kierunki dalszych badań. Na wstępie warto przypomnieć, że do niedawna większość historyków opowiadała się za stosunkowo wczesną datą włączenia Mazowsza do państwa gnieźnieńskiego ${ }^{40}$. Prowadzone ostatnio szczegółowe analizy procesu kształtowania się uchwytnych archeologicznie struktur wczesnopaństwowych wskazują jednak, że nie mogło dokonać się to przed połową X w. ${ }^{41}$ Wydaje się też, że był to proces rozciągnięty w czasie i odbiegający od czytelnego w Wielkopolsce schematu gwałtownej likwidacji starszych centrów władzy oraz wykreowania nowej sieci osadniczej.

Do okresu między połową X a połową XI w. możemy odnosić funkcjonowanie 23 grodów. Spośród nich, co najmniej 10 wybudowano w tym okresie (Grudusk, Grodzisk nad Liwcem, Grzebsk, Płock, Płońsk, Proboszczewice, Serock, Stupsk, Szreńsk, Tańsk), dla 3 jest to prawdopodobne (Ciechanów, Stara Łomża, Wyszogród). Datowanie $5 \mathrm{z}$ nich ustalono na podstawie analiz dendrochronologicznych lub radiowęglowych (Grudusk, Grzebsk, Płońsk, Stupsk, Tańsk). W przypadku 3 obiektów podstawą datowania są analizy znalezisk (Grodzisk nad Liwcem, Płock, Serock).

Na obecnym etapie badań wydaje się pewne, że przynajmniej część „plemiennych" grodów północnego Mazowsza funkcjonowała bez większych przeszkód

39 Zob. m.in.: I. Górska i in., Grodziska; M. Dulinicz, Sieć grodowa Mazowsza Płockiego w XI wieku, [w: ] Lokalne ośrodki wtadzy państwowej w XI-XII wieku w Europie Środkowo-Wschodniej, red. S. Moździoch, Wrocław 1993, s. 47-61, tu s. 54-56.

40 Zob. m.in. H. Łowmiański, Początki Polski. Polityczne i społeczne procesy ksztaltowania się narodu do początku wieku XIV , t. 5, Warszawa 1973, s. 489-492; J. Strzelczyk, Mieszko Pierwszy, Poznań 1992, s. 198; E. Kowalczyk, Momenty geograficzne państwa Bolestawa Chrobrego: na styku historii i archeologii, Kwartalnik Historyczny 107 (2000), nr 2, s. 41-76, tu s. 45-46; G. Labuda, Mieszko I, Wrocław 2002, s. 30-31; A. Gieysztor, Trzy stulecia najdawniejszego Mazowsza (połowa X-połowa XIII w.), [w: Dzieje Mazowsza. Tom 1, red. H. Samsonowicz, Pultusk 2006, s. 109-160, tu s. 114-121.

41 M. Kara, Nowe w archeologii Wielkopolski wczesnośredniowiecznej - 15 lat później, [w:] Stan i potrzeby badań nad wczesnym średniowieczem w Polsce - 15 lat później, red. W. Chudziak, S. Moździoch, Toruń 2006, s. 207-244; tenże, Najstarsze państwo Piastów, s. 234 n. W cytowanych pracach dalsza literatura. 
do około połowy XI w. Do tej grupy zaliczyć można obiekty w Mokrzku, Słupnie, Święcku-Strumianach, Sypniewie, Truszkach-Zalesiu, a zapewne też i w Bródnie Starym. Niektóre grody (Nasielsk, Raciąż) na początku XI w. uległy przebudowie i funkcjonowały w kolejnych stuleciach już jako centra administracji państwowej ${ }^{42}$. Nie wiemy, kiedy i w jakich okolicznościach porzucony został gród w Bocheniu ${ }^{43}$. Najprawdopodobniej w tym okresie nie istniały już grody w Brudzeniu, Bogurzynie i Woli Szydłowskiej, nie wiemy jednak, czy ich upadek związany był w jakikolwiek sposób z ekspansją państwa gnieźnieńskiego ${ }^{44}$.

Najwcześniej po połowie X, a najpóźniej przed połową XI w. na prawobrzeżnym Mazowszu pojawiły się nowe grody, które uznać można za inwestycje władców państwa gnieźnieńskiego. Ze względu na daleki od zadowalającego stan badań nie sposób podać ich kompletnej listy. Z pewnością około $977 \mathrm{r}$. wzniesiono gród w Płońsku i jest to jak dotąd najstarsze dobrze datowane wczesnopaństwowe założenie na terenie Mazowsza (ryc. 4) ${ }^{45}$. Wyróżnia się on przede wszystkim rozmiarami - wały wzniesione w konstrukcji skrzyniowo-przekładkowej, z zastosowaniem charakterystycznych haków u podstawy, otaczały obszar o powierzchni około tha. Wraz z grodem powstał cały zespół osad otwartych, spośród których wyróżnia się badana niedawno osada położona w jego bezpośrednim zapleczu. Dostarczyła ona serii unikalnych znalezisk wskazujących na wysoki status społeczny mieszkańców Płońska w X i XI w. oraz na ich kulturowe powiązania zarówno z wielkopolskimi ośrodkami państwa gnieźnieńskiego, jak i z obszarami Podnieprza i stepów nadczarnomorskich ${ }^{46}$.

42 M. Dulinicz, Sieć grodowa, s. 48-53; tenże, Rozwój osadnictwa, s. 204 n; tenże, Mazowsze we wcześniejszym, s. 99-100; K. Matusiak, Wczesnośredniowieczne osadnictwo; F. Biermann, Sypniewo, s. 180 n; D. Jaskanis, Święck, s. 98n; E. Marczak, „Nikienki”, s. 126. Zob. też J. Ościłowski, Uwarunkowania I, s. 19-27.

43 F. Biermann, M. Dulinicz, Die frühmittelalterliche Siedlung von Bocheń in mittleren Polen, Germania 80 (2002), s. 243-267, tu s. 256-257; M. Dulinicz, Badania grodzisk mazowieckich, s. 153-156.

44 I. Górska i in., Grodziska, s. 140-141, 148-152, 159-161; M. Miśkiewiczowa, Mazowsze płockie, s. 130n; M. Dulinicz, Mazowsze we wcześniejszym, s. 99-100.

45 A. Smoliński, T. Ważny, Analiza dendrochronologiczna próbek drewna z wczesnośredniowiecznego grodziska w Płońsku, woj. mazowieckie, Acta Universitatis Lodziensis. Folia Archaeologica 28 (2011), s. 219-226.

46 A. Smoliński, M. Auch, M. Trzeciecki, Opracowanie wyników ratowniczych badan wykopaliskowych i nadzorów archeologicznych wyprzedzających budowę kanalizacji sanitarnej na ul. 19 Stycznia w Ptońsku w latach 2007-2008 (dalej: Opracowanie I), Warszawa 2013 (maszynopis w archiwum Mazowieckiego Wojewódzkiego Konserwatora Zabytków); ci sami, Opracowanie wyników ratowni- 
Najpewniej już u schyłku X lub na początku XI w. rozpoczęto budowę grodu w Płocku, który być może jeszcze przed połową XI w. awansował do roli ośrodka centralnego o znaczeniu ponadlokalnym ${ }^{47}$. Niewątpliwie w pierwszej połowie XI w. istniał już gród w Proboszczewicach ${ }^{48}$. Na ten okres datować można także powstanie grodu w Serocku, wzniesionego u zbiegu Narwi i Bugu ${ }^{49}$. Stosunkowo wczesną metrykę proponuje się także dla grodu na Farskiej Górze w Ciechanowie, jednak na podstawie publikowanych materiałów z dotychczasowych badań nie można jednoznacznie rozstrzygnąć czasu jego budowy ${ }^{50}$. Brak jest precyzyjnych danych dotyczących datowania grodu wzniesionego na miejscu osady z początków wczesnego średniowiecza na Okrągłej Górze w Wyszogrodzie. Do czasu opublikowania wyników badań wykopaliskowych podstawą jego datowania pozostaje wzmianka w falsyfikacie mogileńskim ${ }^{51}$.

Szczególnie interesująca, ale też wyjątkowo skomplikowana jest sytuacja zarejestrowana na obszarze późniejszej ziemi zawkrzeńskiej. W miejsce 2 grodów „plemiennych" w Bogurzynie i Woli Szydłowskiej, w pierwszej połowie XI w. pojawiła się tu grupa nowych obiektów. Co ciekawe, 3 spośród nich (Grzebsk, Stupsk, Tańsk-Przedbory) możemy zaliczyć do omawianych wyżej niewielkich założeń nawiązujących formą i szczegółami konstrukcji do grodów typu Tornow. Sąsiadowały z nimi grody w Grudusku i Szreńsku, zbliżone raczej do omawianego wyżej Płońska, tak pod względem powierzchni, kształtu, jak i znalezisk. Na podstawie wyrywkowych danych o wynikach badań tych obiektów nie sposób stwierdzić, czy wszystkie funkcjonowały równocześnie i jakie były relacje między nimi ${ }^{52}$.

czych badań wykopaliskowych wyprzedzających budowę tzw. matej obwodnicy w Ptońsku, prowadzonych w sezonie 2010 (dalej: Opracowanie II), Warszawa 2013 (maszynopis w archiwum Mazowieckiego Wojewódzkiego Konserwatora Zabytków).

47 M. Trzeciecki, Początki, s. 70 n; tam też starsza literatura.

48 M. Dulinicz, Sieć grodowa, s. 50-51; tenże, Badania grodzisk mazowieckich, s. 147-150; J. Ościlowski, Czy istniał wczesnośredniowieczny gród w Bielsku na Mazowszu?, Kwartalnik Historii Kultury Materialnej 53 (2005), nr 2, s. 181-189.

49 B. Zawadzka-Antosik, Badania na grodzisku wczesnośredniowiecznym w miejscowości Serock, pow. Nowy Dwór Mazowiecki, Wiadomości Archeologiczne 33 (1968), s. 362-367; I. Górska i in., Grodziska, s. 121-122.

50 I. Górska, Badania sondażowe na Farskiej Górze w Ciechanowie, Wiadomości Archeologiczne 34 (1969), s. 436-442; I. Górska i in., Grodziska, s. 31-34.

51 Tamże, s. 169-170.

52 I. Górska i in., Grodziska, s. 62-63, 130-133, 140-145; M. Miśkiewiczowa, Mazowsze ptockie, s. 130 n; M. Piotrowski, Szreńsk - miasto zapomniane (zarys dziejów), Warszawa 1986, s. 20-23; 
Nieliczne są przesłanki do datowania grodów położonych w północno-wschodniej części omawianego terytorium. Jedynie hipotetycznie z okresem przed połową XI w. możemy wiązać budowę pierwszego grodu w Starej Łomży ${ }^{53}$. Z odmienną sytuacją mamy do czynienia na Mazowszu wschodnim. Na podstawie analizy materiałów z grodzisk położonych w dorzeczu Liwca, do pierwszej połowy XI w. odnosić możemy w sposób pewny jedynie budowę imponującego rozmiarami założenia w Grodzisku nad Liwcem $^{54}$. Należy natomiast podkreślić, że brak jest danych o budowie jakichkolwiek nowych grodów na Mazowszu południowo-zachodnim, między Wisłą, Pilicą i Bzurą.

Cechą charakterystyczną omawianych tu grodów jest ich lokalizacja w obrębie pustek osadniczych lub w strefach granicznych między większymi skupiskami osadnictwa (Płock, Płońsk, Proboszczewice, Serock). Położenie części z nich wydaje się być ściśle związane z biegiem dużych rzek regionu (Płock, Wyszogród, Serock, Stara Łomża). Lokowane są w miejscach o bardzo dobrej widoczności, zapewniających możliwość kontroli dolin rzek. Od grodów okresu „plemiennego” odróżniają się mniej regularnym planem i powierzchnią wynoszącą około 1 ha, wyjątkiem jest tu założenie w Grodzisku nad Liwcem zajmujące obszar prawie 6 ha. W przypadku Płocka i Płońska stwierdzono także zblizzoną, skrzyniowo-przekładkową konstrukcję wałów ${ }^{55}$. Do najbardziej wyrazistych cech charakterystycznych kultury materialnej nowych grodów można zaliczyć masowe występowanie zestandaryzowanych form silnie obtaczanych naczyń glinianych, a także obecność przedmiotów uznawanych za interregionalne wyznaczniki wysokiego statusu społecznego, często o czytelnych nawiązaniach do strefy dorzecza Dniepru ${ }^{56}$.

Przedstawiona wyżej charakterystyka grodów mazowieckich w pierwszej połowie XI w. pozwala przypuszczać, że na interesującym nas terytorium istniał jakiś „okres przejściowy”, kiedy starsze - umownie „plemienne” - ośrodki centralne w miarę harmonijnie funkcjonowały obok nowych. Ten okres zakończył się około połowy XI w.

M. Dulinicz, Sieć grodowa, s. 50-51; M. Dulinicz, W. Moszczyński, Grody pogranicza nad górną Wkrą: system czy chaos?, [w: ] Pogranicze polsko-pruskie i krzyżackie 2, red. K. Grążawski, Włocławek 2007, s. $61-88$.

53 M. Miśkiewiczowa, Mazowsze płockie, s. 187, 191, 197-198; J. Ościłowski, Sieć grodowa, s. 88-89, tam też dalsza literatura.

54 W. Wróblewski, U źródet, s. 214-216.

55 M. Trzeciecki, Gród na Wzgórzu Tumskim, [w:] Płock Wczesnośredniowieczny, red. A. Gołembnik, Warszawa 2011, s. 101-148, tu s. 110-117; A. Smoliński, M. Auch, M. Trzeciecki, Opracowanie I.

56 M. Trzeciecki, Początki, s. 94-99; tenże, Ceramika płocka, s. 182-185; A. Smoliński, M. Auch, M. Trzeciecki, Opracowanie II; W. Pastuszka, Grudusk. 
wraz z porzuceniem grodów w Słupnie, Sypniewie i niektórych innych tego typu obiektów. Być może nieprzypadkowo zbiega się to z wydarzeniami związanymi ze stłumieniem rebelii Miecława. Ponowne włączenie zbuntowanej prowincji w obręb państwa wygenerowało niewątpliwie konieczność uporządkowania sieci ośrodków centralnych. Działania te, dokonane w przeciągu drugiej połowy XI w., mogły być częścią procesu całościowej przebudowy struktury gospodarczej i administracyjnej państwa, której celem było zapewnienie stabilnych podstaw funkcjonowania aparatu władzy.

$\mathrm{W}$ drugiej połowie XI w. na omawianym obszarze istniały 24 grody. Tylko 4 spośród nich wybudowano w tym okresie (Barchów, Czersk, Stara Warka, Wizna), kolejnych 7 możemy jedynie ogólnie datować na XI w. (Grodziszcze Mazowieckie, Grodzisk nad Orzem, Ławsk, Łochów, Susk, Wyłazy, Zakroczym) ${ }^{57}$. Nadal użytkowano 13 grodów wzniesionych przed połową XI w. (Ciechanów, Grodzisk nad Liwcem, Grudusk, Grzebsk, Nasielsk, Płock, Płońsk, Raciąż, Serock, Stara Łomża, Szreńsk, Święck, Wyszogród). W tym okresie ostatecznie porzucone zostały niektóre grody o genezie „plemiennej” - Słupno, Mokrzk, Sypniewo, Święck-Strumiany, a także te powstałe już po połowie X w. - Tańsk-Przedbory i Proboszczewice. Szczególnie interesująca jest kwestia ostatniego $\mathrm{z}$ wymienionych, uznawanego za jedno z pierwszych założeń wczesnopiastowskich, położonego w obrębie dużego skupiska osadniczego o „plemiennej” jeszcze genezie. Być może jego likwidacja związana była z rosnącym znaczeniem niedalekiego Płocka ${ }^{58}$.

Datowania archeologiczne poszczególnych grodzisk płockiej części Mazowsza przynoszą obraz terytorium pokrytego siecią stosunkowo regularnie rozmieszczonych ośrodków grodowych, którym towarzyszą znaczne skupiska osadnicze. Odległość pomiędzy nimi jest różna, z reguły jednak oscyluje wokół $30 \mathrm{~km}$, co warunkowało sprawną komunikację. Można przypuszczać, że pełniły one przede wszystkim funkcję centrów administracji terytorialnej, stanowiły miejsca gromadzenia świadczeń i egzekwowania władzy książęcej ${ }^{59}$. W „grodowym pejzażu” tej części Mazowsza

57 I. Górska i in., Grodziska, s. 15-17, 53-57, 129-130, 161-164, 169-170; W. Wróblewski, U źródet, s. 214; J. Ościłowski, Sieć grodowa, s. 87; tenże, Badania archeologiczne grodzisk pótnocno-wschodniego Mazowsza w latach 2008-2009, [w:] Grody średniowiecznego Mazowsza. Księga poświęcona pamięci Marka Dulinicza, red. M. Żurek, M. Krasna-Korycińska, Warszawa 2015, s. 63-87, tu s. 64-78; P. Urbańczyk, Fazy użytkowania Wzgórza Zamkowego w Czersku na podstawie badań z lat 1974-1983, [w: ] Czersk, Wzgórze Zamkowe. Badania 1974-1983, red. P. Urbańczyk, M. Trzeciecki, Warszawa 2016, s. 69-130, tu s. 81-86.

58 J. Ościłowski, Czy istniał, s. 188-189; M. Trzeciecki, Początki Płocka, s. 96-98.

59 M. Dulinicz, Sieć grodowa, s. 59-61; zob. też E. Kowalczyk, [rec.:] Dulinicz M., Sieć grodowa Mazowsza Płockiego w XI wieku. W: S. Moździoch (red.), Lokalne ośrodki władzy państwowej w XI-XII 
wyróżnia się łańcuch obiektów położonych na prawym brzegu Wisły i dolnej Narwi - od Płocka po Serock - poświadczający zapewne rosnące znaczenie wodnego szlaku wiślańsko-bużańskiego. W omawianym okresie wyraźnie wzrosła rola Płocka - siedziby Władysława Hermana, a od około 1075 r. stolicy nowej diecezji. Materialnym śladem centralnych w skali prowincji funkcji grodu na Wzgórzu Tumskim są relikty katedry i co najmniej dwóch innych budowli sakralnych wzniesionych przed schyłkiem XI w. ${ }^{60}$

Na Mazowszu północno-wschodnim obok grodu w Starej Łomży powstało założenie w Wiźnie, zlokalizowane w pobliżu ujścia Biebrzy do Narwi ${ }^{61}$. Najprawdopodobniej na okres po połowie XI w. można też datować budowę grodu w Grodzisku nad Orzem oraz niewielkich obiektów w Susku i Ławsku ${ }^{62}$. Wydaje się jednak, że zagospodarowanie północno-wschodnich „kresów” dokonało się dopiero w następnym stuleciu. Na Mazowszu południowo-wschodnim, obok Grodziska nad Liwcem, po połowie XI w. funkcjonowały co najmniej 4 założenia (Barchów, Łochów, Grodziszcze Mazowieckie i Wyłazy), jednak stan ich przebadania utrudnia precyzyjne określenie chronologii i wzajemnych relacji miedzy nimi ${ }^{63}$. Znaczące zmiany zaszły natomiast w południowo-zachodniej części omawianego tu terytorium. W pierwszym rzędzie należy tu wymienić wybudowany po połowie XI w. gród w Czersku, który zaczął pełnić funkcję ośrodka centralnego dla obszarów miedzy środkową Wisłą, dolną Pilicą i Bzurą, potwierdzoną wzniesieniem tu jeszcze przed końcem XI w. murowanego kościoła ${ }^{64}$. W tym samym czasie powstał też zapewne gród w Starej Warce, położony w pobliżu ujścia Pilicy do Wisły ${ }^{65}$. Z tym okresem próbuje się także wiązać budowę grodu w Grójcu, sam obiekt pozostaje jednak niezlokalizowany ${ }^{66}$.

wieku w Europie Środkowo-Wschodniej, Wroctaw, s. 47-61, Kwartalnik Historii Kultury Materialnej 42 (1994), nr 3-4, s. 372-380.

60 A. Bukowska, Relikty architektury wczesnośredniowiecznej-formy i datowanie, [w:] Ptock Wczesnośredniowieczny, red. A. Gołembnik, Warszawa 2011, s. 149-216, tu s. 157-158, 187-189, 200-201; M. Trzeciecki, Gród, s. 137-142. W cytowanych pracach starsza literatura.

61 J. Ościłowski, Sieć grodowa, s. 87-89, tam starsza literatura.

62 I. Górska i in., Grodziska, s. 55-57; J. Ościłowski, Badania archeologiczne, s. 65-78.

63 W. Wróblewski, Uźródet, s. 214-219.

64 P. Urbańczyk, Fazy użytkowania, s. 81-90; M. Trzeciecki, Organizacja przestrzeni i zabudowa Wzgórza Zamkowego: XI-XIV w., [w:] Czersk, Wzgórze Zamkowe. Badania 1974-1983, red. P. Urbańczyk, M. Trzeciecki, Warszawa 2016, s. 131-164, tu s. 140-162.

65 I. Górska i in., Grodziska, s. 129-130.

66 Tamże, s. 61. 
Podsumowując ten z konieczności skrótowy i niepełny przegląd problematyki najstarszych założeń grodowych Mazowsza, warto wskazać kilka cech wyróżniających obiekty z tego regionu. Podkreślić należy przede wszystkim niewielką liczbę grodów z okresu „plemiennego” i wyraźną ich koncentrację na północ od linii środkowej Wisły i Bugu. Zwraca uwagę zestandaryzowana forma najstarszych założeń, znajdująca bezpośrednie analogie w położonych dalej na zachód grodach typu Tornow. Chronologia najstarszych mazowieckich grodów tego typu wskazuje, że ich budowa była częścią znacznie szerszego procesu społeczno-kulturowego, ogarniającego rozległe obszary od Łaby aż po Narew. Cechą wyróżniającą jedenastowieczne Mazowsze jest natomiast „długie trwanie” grodów zbudowanych jeszcze przed połową X w., a także niewielka grupa grodów o formach „tornowskich” wzniesiona niewątpliwie na początku XI w.

Przypomnieć tu należy także sygnalizowaną już koegzystencję obiektów o genezie „plemiennej” i wczesnopaństwowej, trwającą co najmniej do połowy XI w. Pierwsze założenia, które możemy z dużą dozą prawdopodobieństwa wiązać $\mathrm{z}$ ekspansją państwa gnieźnieńskiego pojawiły się pod koniec X w. na Mazowszu płockim, do tego też regionu ograniczała się aktywność budowlana. $Z$ rozległymi obszarami na wschód od środkowej Wisły wiązać można co najwyżej 2 grody - w Grodzisku nad Liwcem i Starej Łomży. Jedenastowieczne grody „państwowe” wydają się także obiektami zestandaryzowanymi pod względem rozmiarów i technik budowy wałów, zagadnienie to wymaga jednak dalszych szczegółowych badań. Zmiany dokonujące się po połowie XI w. ograniczały się do „uporządkowania” sytuacji w płockiej części Mazowsza, gdzie porzucono ostatecznie większość grodów okresu „plemiennego”. Widoczne są też inwestycje w dorzeczu Narwi i Bugu. Dopiero na okres po połowie tego stulecia można datować najstarsze „państwowe” założenia grodowe na Mazowszu południowo-zachodnim. $\mathrm{Z}$ tym okresem wiąże się też pojawienie się pierwszych kościołów w Płocku i Czersku, które to ośrodki wyrastają na główne centra kształtującej się prowincji.

Jak już wspomniano na wstępie, nakreślony tu obraz jest w znacznej mierze roboczą hipotezą, z konieczności budowaną na lakonicznych wzmiankach lub wstępnych sprawozdaniach z badań. Można w tym miejscu zastanowić się, czy nie przyszedł czas na reedycję Grodzisk Mazowsza i Podlasia, uzupełnionych o wyniki prac prowadzonych w ostatnim trzydziestoleciu. Wydaje się jednak, że żaden, nawet najbardziej wyczerpujący katalog nie zastąpi monografii poszczególnych stanowisk, prezentujących pełen zestaw uzyskanych danych i znalezisk. Postulat ten dotyczy większości spośród wymienionych tu grodzisk. Kluczowe znaczenie wydaje się mieć zwłaszcza udostęp- 
nienie wyjątkowo interesujących wyników badań w Płońsku, obejmujących gród i jego zaplecze osadnicze, a także niedawnych wykopalisk ratowniczych w Grudusku. Od przeszło 30 lat na publikację oczekują materiały z jednego z najważniejszych wczesnośredniowiecznych stanowisk regionu - Wyszogrodu. Swoich monografii winny doczekać się też grodziska, które na początku lat dziewięćdziesiątych XX w. uzyskały precyzyjne datowania. Do tej grupy należy - przypomnijmy - większość omawianych tu obiektów „plemiennych”, nawiązujących do grodów typu Tornow. Trudno będzie natomiast spełnić postulat udostępnienia efektów wieloletnich badań Starej Łomży, najważniejszego założenia na Mazowszu północno-wschodnim, nieznany jest bowiem los dokumentacji, a zgromadzone w Muzeum Ziemi Łomżyńskiej materiały pozbawione są danych dotyczących kontekstu znalezienia.

Bez wznowienia prac wykopaliskowych niemożliwe wydaje się rozstrzygnięcie wielu podstawowych problemów dotyczących przede wszystkim datowania dużej grupy obiektów jedenastowiecznych. Pierwsze miejsce na tej liście zajmuje wspominane tu wielokrotnie grodzisko w Proboszczewicach. Obok niego znaleźć się powinny grody wiązane z okresem „plemiennym”, które odbiegają od „tornowskiego” standardu - Brudzeń Duży i Zwola Poduchowna. Wydaje się też, że ponowne wykopaliska to jedyna możliwość rzetelnej analizy złożonej problematyki grodu w Starej Łomży i terytorium nad środkową Narwią. Warto także wskazać na konieczność powrotu do studiów osadniczych, zapoczątkowanych w latach dziewięćdziesiątych XX w. monografią doliny Słupianki. Niezbędne przy tym wydaje się równoległe prowadzenie badań paleośrodowiskowych, w szerszym zakresie zrealizowanych dotąd jedynie w Nasielsku ${ }^{67}$. Na zakończenie należy zwrócić uwagę na niewykorzystany dotąd potencjał badań porównawczych i podjęcie próby spojrzenia na kulturowy krajobraz Mazowsza w X i XI w. z perspektywy położonych na północ ziem pruskich, a także z pogranicza wschodniej i zachodniej Słowiańszczyzny, kształtującego się wówczas nad górną Narwią i środkowym Bugiem.

Nadesłany: 2 XII 2017

Nadesłany po poprawkach recenzyjnych: 11 III 2018

Zaakceptowany: 15 III 2018

\footnotetext{
67 M. Błoński, P. Szwarczewski, Zapis działalności człowieka w osadach wypetniajacych dno doliny Nasielnej w Nasielsku, Landform Analysis 9 (2008), s. 272-275; ci sami, Antropogeniczne przeksztatcenia doliny Nasielnej w sąsiedztwie wczesnośredniowiecznego grodziska w Nasielsku, Archeologia Polski 43 (2008), s. 291-317.
} 
dr Maciej Trzeciecki

Instytut Archeologii i Etnologii

Polska Akademia Nauk

al. Solidarności 105

00-140 Warszawa

misiek042003@gmail.com

\section{„Tribal" and "early State" strongholds in Mazovia $\left(9^{\text {th }}-11^{\text {th }} \mathbf{c}\right.$. $)$. State of the art, research questions and interpretive possibilities}

The following text is dedicated to early medieval strongholds built in Mazovia between the end of the $9^{\text {th }}$ and the end of the $11^{\text {th }}$ c. At least 39 sites can be dated to that period, among them 14 were built in the so-called "tribal" period, while the other ones are associated with the early Piast state structures. One should emphasize the small number of "tribal" strongholds and their concentration to the north of the middle Vistula river. The standardized form of the oldest fortifications refers directly to the so-called Tornow type. Apparently, the first strongholds associated with the expansion of the early Piast state appeared at the end of the $10^{\text {th }} \mathrm{c}$. in the western Mazovia and the main building activity was limited to that area until the end of the $11^{\text {th }}$ c. Noteworthy, at least up to the mid- $11^{\text {th }} \mathrm{c}$. both "tribal" and early-state strongholds existed near to each other. 


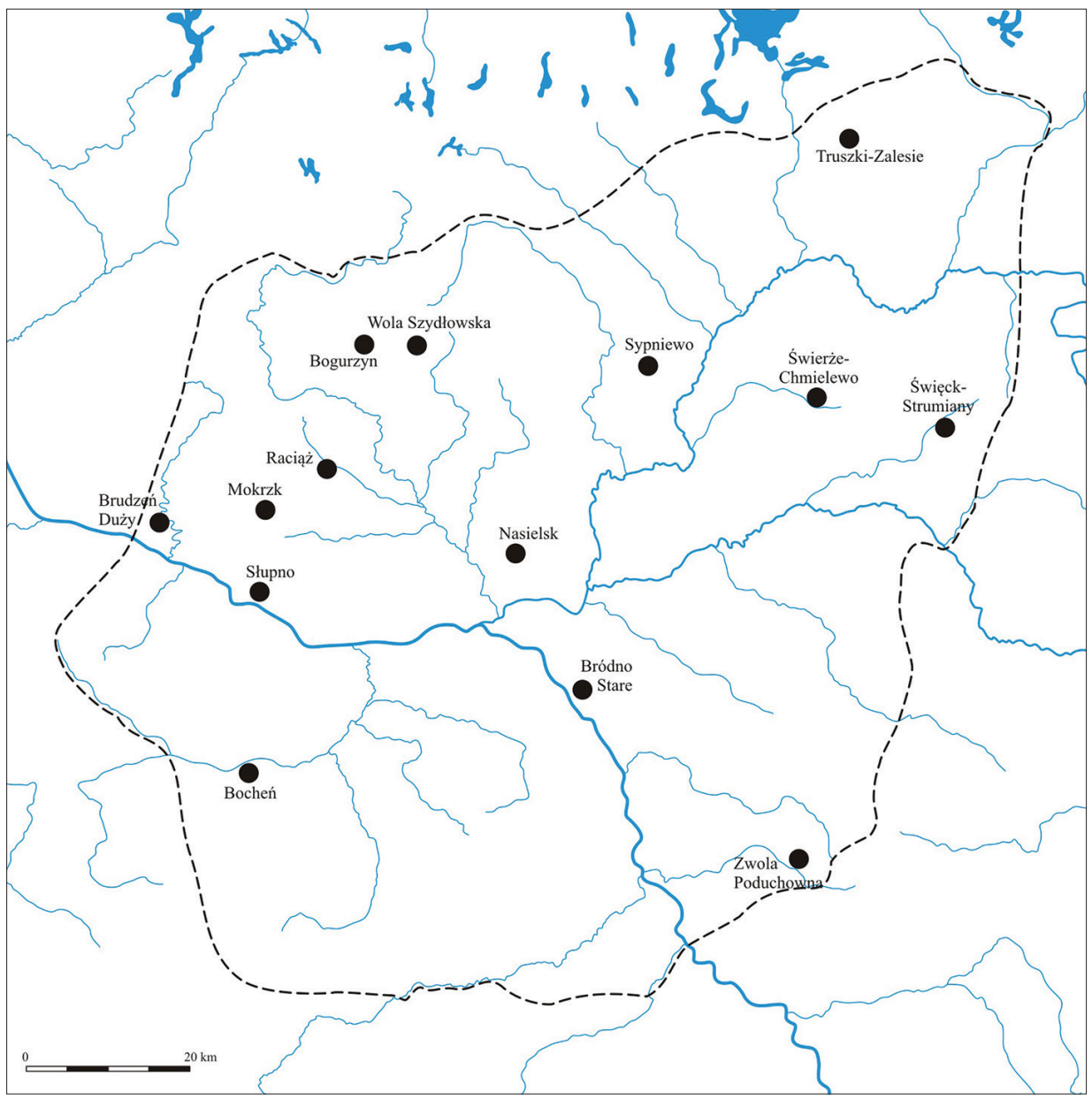

Ryc. 1. Grody Mazowsza w pierwszej połowie X w. Opr. M. Trzeciecki (Figure 1. Mazovian strongholds in the $1^{\text {st }}$ half of the $10^{\text {th }} \mathrm{c}$. By M. Trzeciecki). 


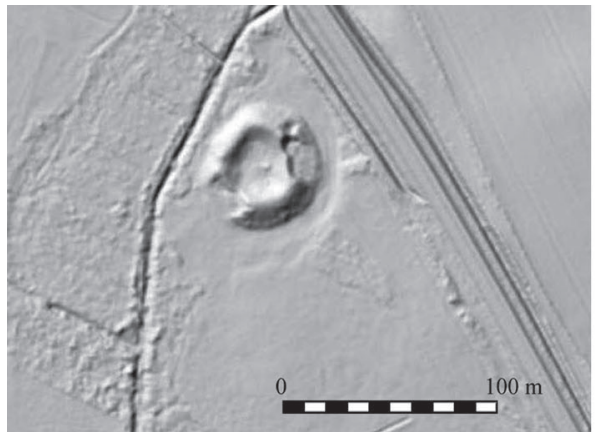

1

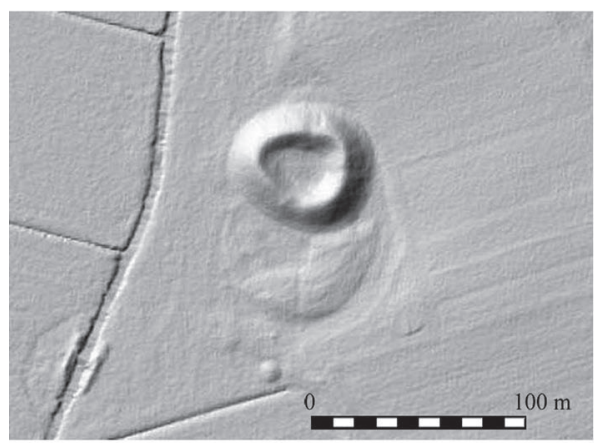

3

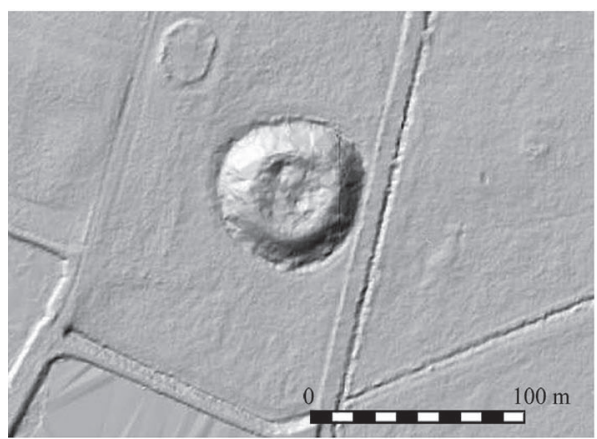

5

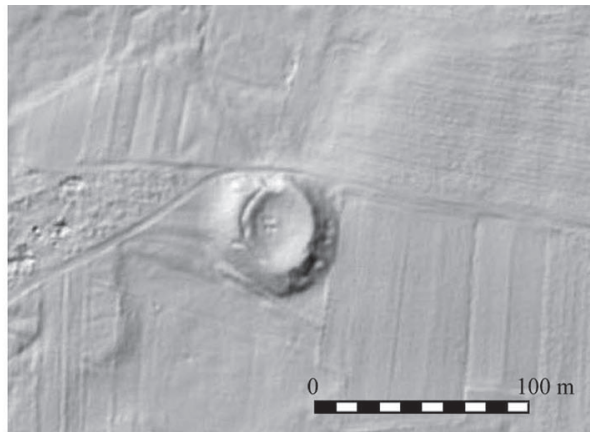

2

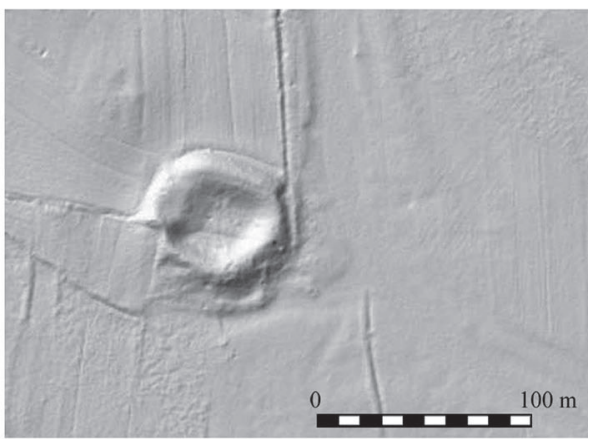

4

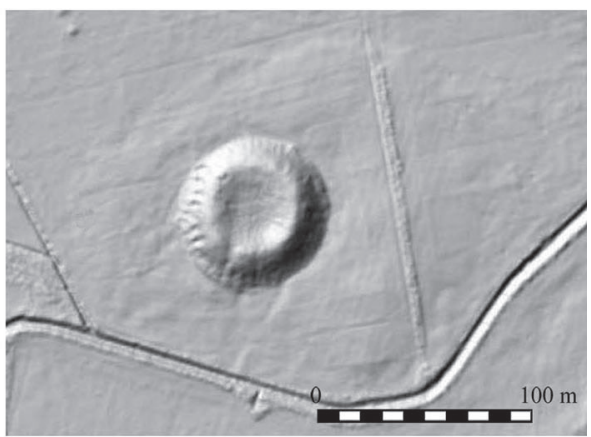

6

Ryc. 2. Grodziska datowane na schyłek IX - pierwszą połowę X w. (1-4) i pierwszą połowę XI w. (5-6). 1 - Wola Szydłowska, 2 - Bogurzyn, 3 - Sypniewo, 4 - Słupno, 5 - Grzebsk, 6 - Stupsk. Źródło: www.geoportal.pl (Figure 2. Strongholds dated to the late $9^{\text {th }}-1^{\text {st }}$ half of the $10^{\text {th }} \mathrm{c}$. (1-4), and $1^{\text {st }}$ half of the $11^{\text {th }}$ c. (5-6). 1 - Wola Szydłowska, 2 - Bogurzyn, 3 - Sypniewo, 4 Słupno, 5 - Grzebsk, 6 - Stupsk. Source: www.geoportal.pl). 

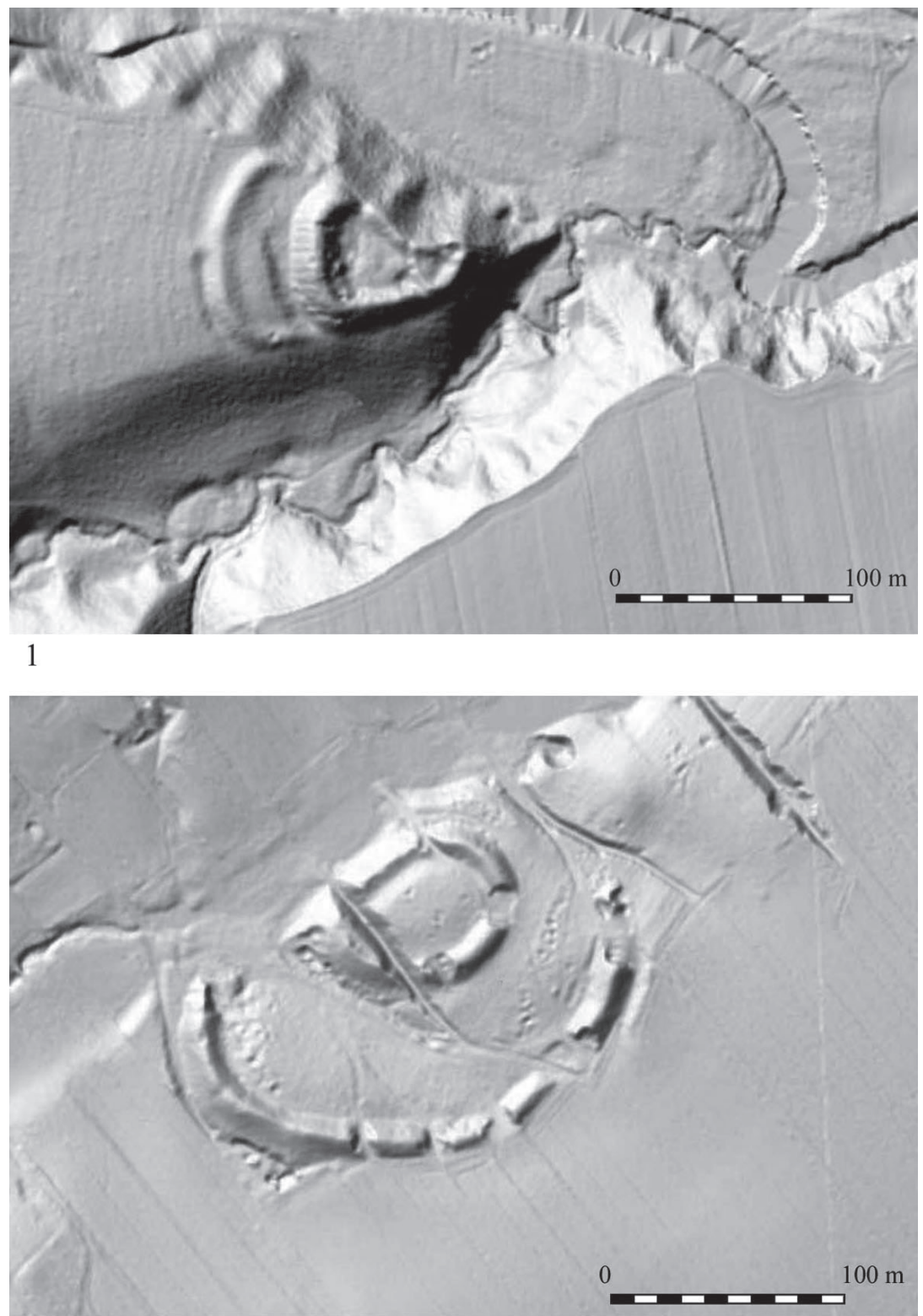

Ryc. 3. Grodziska datowane ogólnie na X w. 1 - Brudzeń Duży, 2 - Zwola Poduchowna. Źródło: www.geoportal.pl (Figure 3. Strongholds dated roughly to the $10^{\text {th }}$ c. 1 - Brudzeń Duży, 2 Zwola Poduchowna. Source: www.geoportal.pl). 


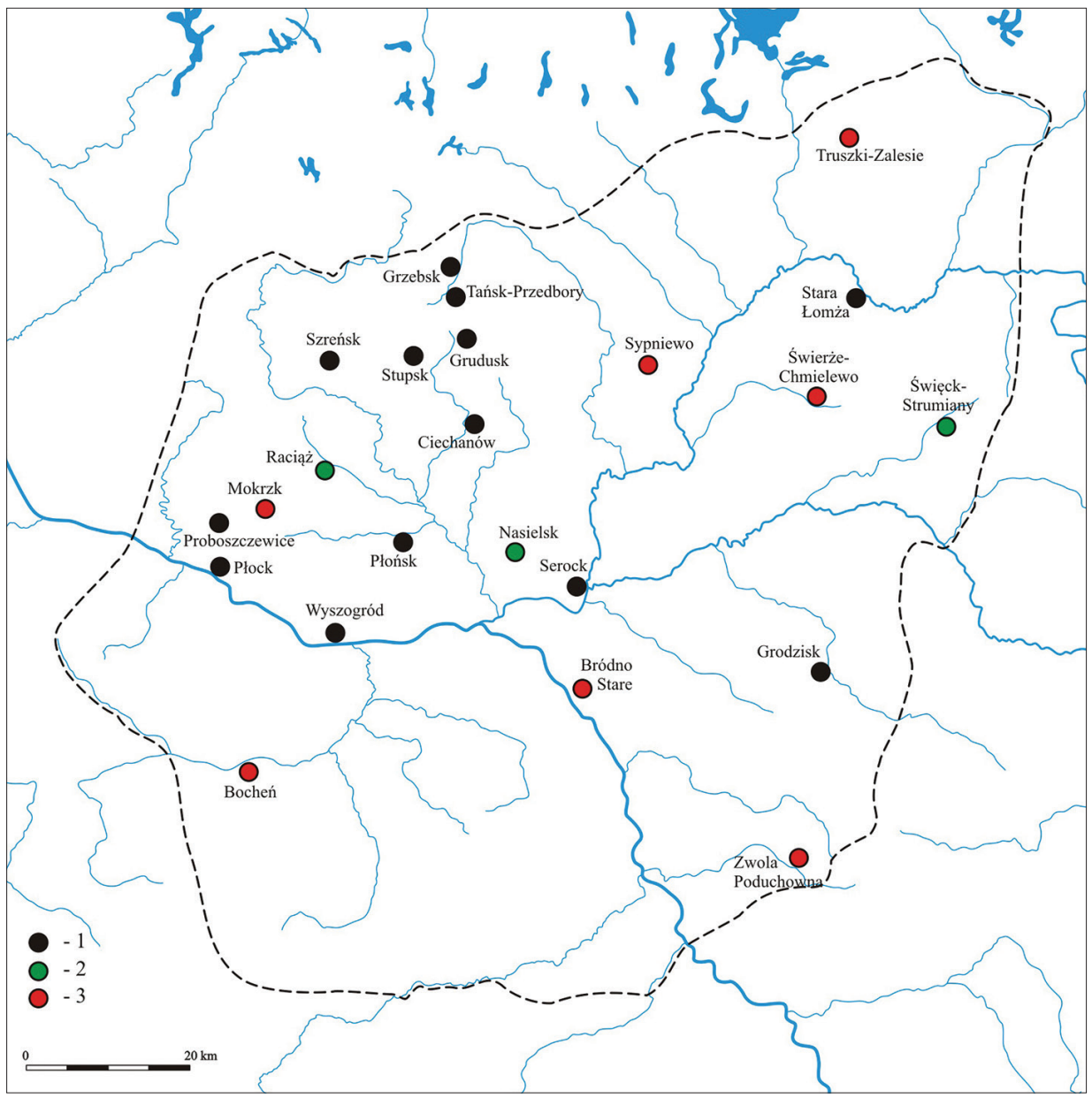

Ryc. 4. Grody Mazowsza w pierwszej połowie XI w. 1 - grody wybudowane w pierwszej połowie XI w., 2 - grody wybudowane w pierwszej połowie X w. i przebudowane w pierwszej połowie XI w., 3 - grody wybudowane w pierwszej połowie X w. i opuszczone w około połowy XI w. Opr. M. Trzeciecki (Figure 4. Mazovian strongholds in the $1^{\text {st }}$ half of the $11^{\text {th }} \mathrm{c} .1$ - strongholds built in the $1^{\text {st }}$ half of the $11^{\text {th }}$ c., 2 - strongholds built in the $1^{\text {st }}$ half of the $10^{\text {th }} \mathrm{c}$. and rearranged in the $1^{\text {st }}$ half of the $11^{\text {th }}$ c., 3 - strongholds built in the $1^{\text {st }}$ half of the $10^{\text {th }} \mathrm{c}$. and abandoned in the mid- $11^{\text {th }}$ c. By M. Trzeciecki). 


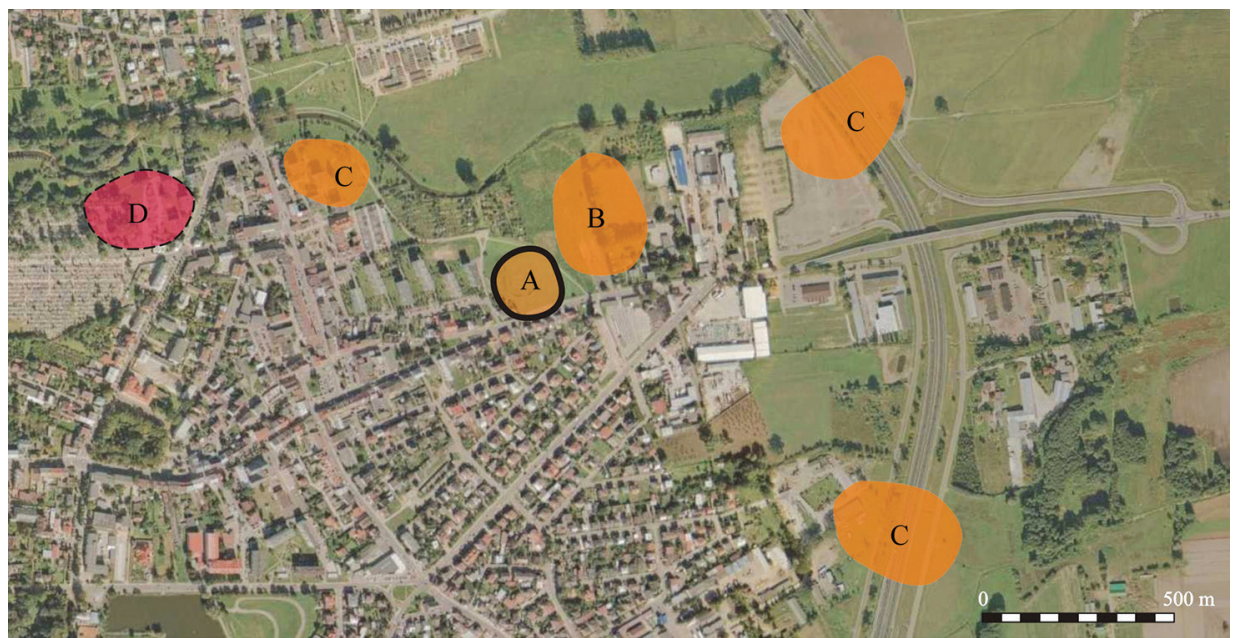

1
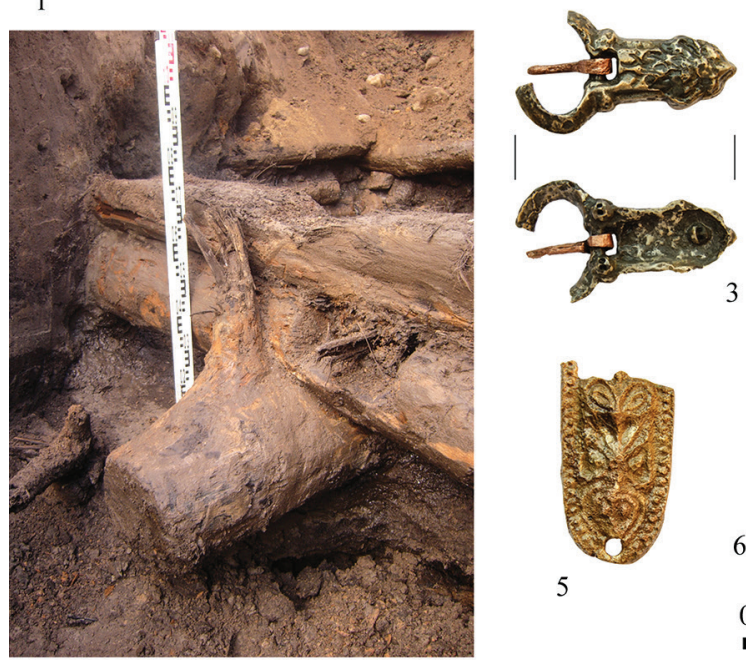

\section{3}
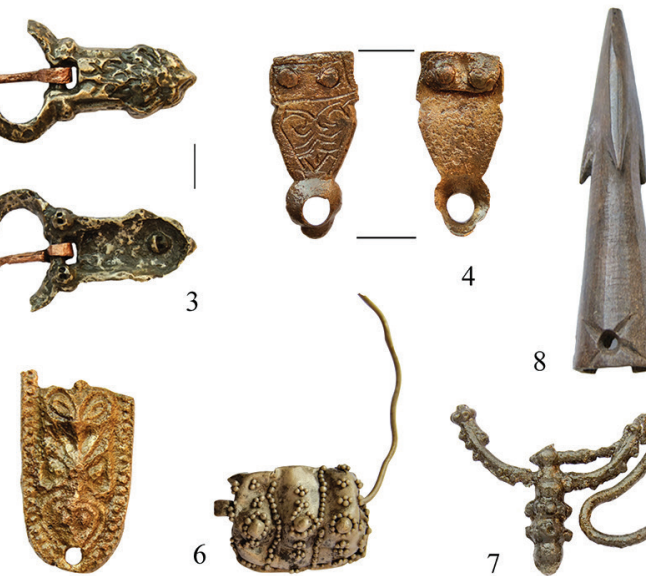

4

5

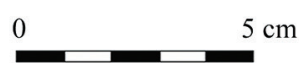

2

Ryc. 5. Płońsk w XI w. 1 - zespół osadniczy: A - gród, B - osada podgrodowa, C - inne osady, D - cmentarzysko. Opr. M. Trzeciecki; 2 - relikty wału grodu z widoczną konstrukcją hakową. Fot. A. Smoliński; 3-8 - znaleziska z osady podgrodowej (B): stop miedzi (3-5), srebro (6-7), kość (8). Fot. M. Trzeciecki (Figure 5. Płońsk in the 11th c. 1 - settlement complex: A - stronghold, B - borough, C - open settlements, D - cemetery. By M. Trzeciecki; 2 - relics of wooden rampart with element of the so-called hook construction. Photo by A. Smoliński; 3-8 - artifacts from the excavations in the borough (B): copper alloy (3-5), silver (6-7), bone (8). Photo by M. Trzeciecki). 


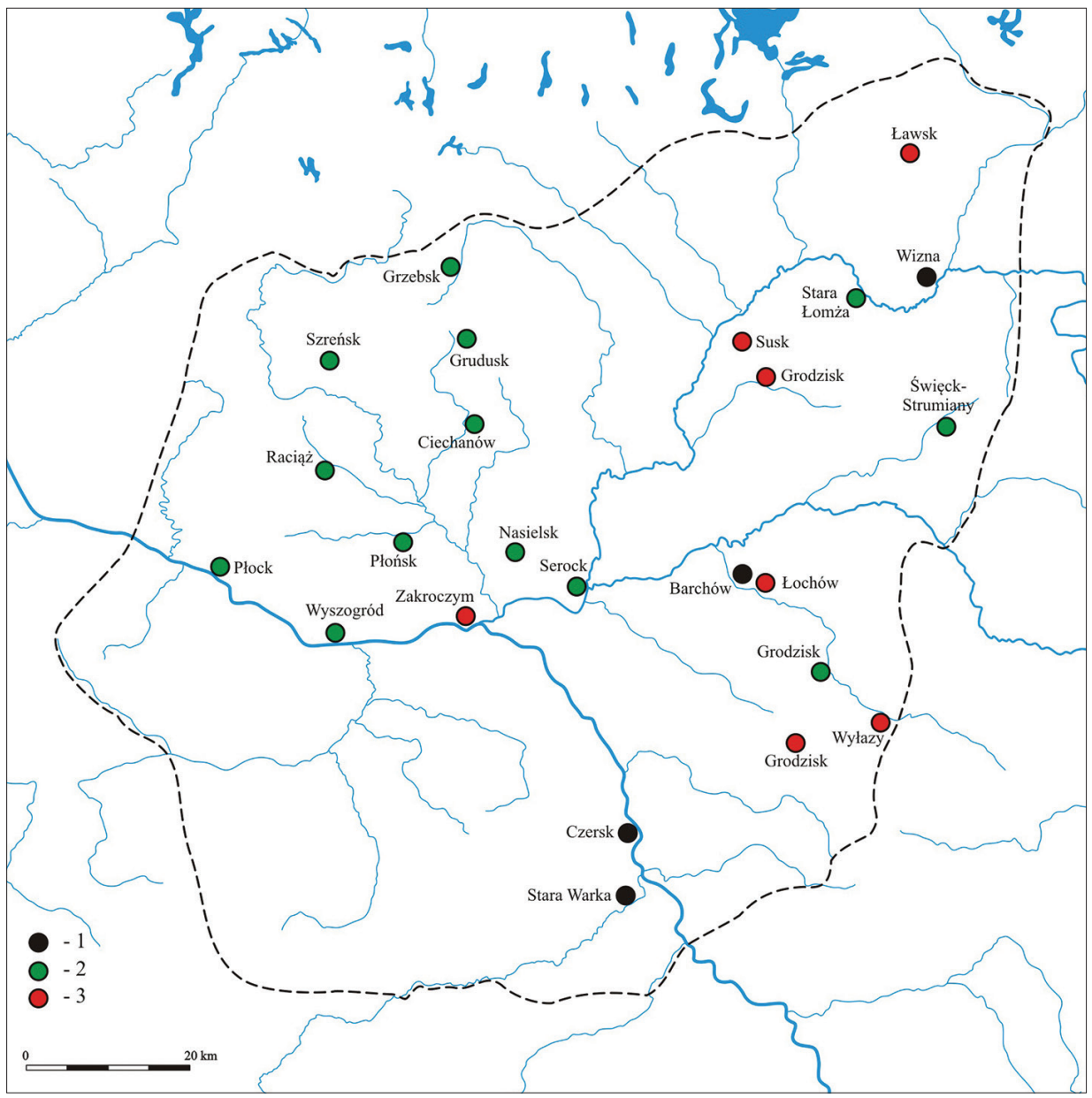

Ryc. 6. Grody Mazowsza w drugiej połowie XI w. 1 - grody wybudowane w drugiej połowie XI w., 2 - nadal funkcjonujące grody wybudowane przed połową XI w., 3 - grody datowane ogólnie na XI w. Opr. M. Trzeciecki (Figure 6. Mazovian strongholds in the $2^{\text {nd }}$ half of the $11^{\text {th }} \mathrm{c}$. 1 - strongholds built in the $2^{\text {nd }}$ half of the $11^{\text {th }}$ c., 2 - strongholds built before the mid- $11^{\text {th }}$ c., still functioning; 3 - strongholds dated roughly to the $11^{\text {th }}$ c. By M. Trzeciecki). 